\title{
Propaedeutics in Practice: Islamic Legal Studies and the Public Sphere
}

\author{
Timothy Gutmann
}

\begin{abstract}
In this paper, I outline a propaedeutics of Islamic legal studies. I am using the term "propaedeutic" to refer to scholarship and pedagogy that introduces audiences to new material in a way that structures their curiosities and asks them to rethink commonplace familiar situations and assumptions. Those who teach about Islamic law in North American Islamic studies are working in an environment shaped by distinctive anxieties and preconceptions. Engaged scholarship informed by thinkers such as Wael Hallaq and Talal Asad seeks to disentangle conceptions of law from modern expectations of law enforcement, codification, and the supervisory neutrality of the state to consider other deliberations and practices of justice. Such propaedeutic scholarship should suggest how religious legal authority deals with more than just "spiritual" and "personal" matters. Imprecise introduction to the idea that Islamic legal opinion is non-binding can unintentionally imply that such opinion makes only moral suggestion that one chooses to follow or not. Scholars critical of Max Weber's judgment that Islamic jurisprudence amounts to little more than arbitrary invocations of authority should be careful not to present Islamic jurists as merely creatively "free" to be unsystematic and their decisions inconsequential if following them is not coerced. Drawing on the work of Hussein Agrama, I explore the idea of fatwa discernment as guiding counsel directed not at adversarial procedure but at ethical self-formation.
\end{abstract}

Timothy Gutmann is a scholar of religion and modernity who works on Islamic and East Asian traditions. He has written on mass education, the minority question, and the politics of secularism. He teaches at the University of Chicago.

Gutmann, Timothy. 2020. "Propaedeutics in Practice: Islamic Legal Studies and the Public Sphere." American Journal of Islam and Society 37, nos. 3-4: 1-23 • doi: 10.35632/ajis.v37i3-4.744 Copyright $\odot 2020$ International Institute of Islamic Thought 
Finally, I consider Saba Mahmood's account of religious difference to suggest how Islamic legal traditions might complicate liberal ideas of jurisdiction.

\section{Introduction}

Liberal political thought and practice are persistently troubled by questions of whether and how groups of people can belong to a society when they are seen as distinct from the majority. Accordingly, the Muslim question and Islamic legal practices are debated in Europe and North America, the nature of the state and society are themselves at issue. Even if academic scholars of Islamic legal studies do not want to be part of a public sphere in which these issues are debated, they often find themselves there. In this situation, this article proposes a propaedeutic approach to public scholarship and teaching. This propaedeutic addresses the particular anxieties of legal and religious difference in liberalism in North America as elsewhere. The propaedeutic considers how scholars can think and teach about Islamic legal traditions in ways that ask their audiences to reconsider commonly-held assumptions and beliefs about what law and religion are and how they interact. However, when scholars do contrast those familiar commonplaces with Islamic legal theory and practice, they must be careful not to suggest that the theory and styles of reasoning endemic to Islamic traditions are incommensurate with modern ones. Scholars often have to confront two opposite but persistent caricatures of Islamic law. Depending on the context, "sharī'a" might either represent a menacing, coercive force that stifles the freedom to dissent, or alternatively, it can be seen as an idiosyncratic, individualistic intellectual exercise that has little consequence in the real world. To avoid either of these caricatures, I suggest looking to the propaedeutic potential within Islamic legal traditions themselves. I also argue for deepening our discussions of the nature of the law as such by thinking about what its constituent conceptions such as counsel and jurisdiction can tell us about legal subjectivity and the recognition of difference.

Propaedeutics is a field of pedagogical and theoretical thinking concerned with how to introduce people to large and complex subjects in ways that encourage further curiosity and structure it appropriately. In this article, I am specifically concerned with a propaedeutics of Islamic legal traditions in a context in which prejudice, misunderstanding, and distortion of this subject is commonplace-that is a propaedeutics specific to the contemporary North American context. However, this propaedeutics draws on examples from Islamic intellectual history and other traditions as well. ${ }^{1}$ 
For example, the Ihya' ' ulūm al-din (The Revival of Religious Learning) by Abu Hamid al-Ghazali (1058-1111) $)^{2}$ presents such an organon. In the introductory Kitāb al- ${ }^{c} i l m$ (The Book of Knowledge), al-Ghazali asserts that a student cannot approach topics like philosophy, theology, and mysticism without a grounding in law, hadith, and other exoteric fields. ${ }^{3} \mathrm{Al}-\mathrm{Ghazali}$ wants to make sure that students understand the basics of belief before they approach perilous questions. This is the simple part of al-Ghazali's propaedeutical agenda. However, he also makes clear that different audiences (or publics) in the community need different kinds of knowledge and different forms of authority to guide them. He is particularly concerned that people who need to seek counsel on matters of ritual practice or law can find competent authorities to guide them toward the kind of religion that is most acceptable to God and will serve believers well in his esteem. Al-Ghazali believes the community needs propaedeutic instruction on practical ritual matters, and that this community need contributes to (but is distinct from) the desire of the 'ulamä' to produce erudite discourses on nuanced points of theology. Al-Ghazali does not denigrate the latter to praise the former (assuming everything is done properly). He rather recognizes different kinds of propaedeutic politics.

By analogy, I argue that a modern academic scholarly community that is concerned with spreading knowledge about Islamic legal thinking must address different publics in ways that counter prejudice and that give opportunity for reflection. The propaedeutic I propose here takes a critical awareness of the broader contexts in which scholars write, teach, and are asked questions. In the study of the law, the project of Critical Legal Studies (CLS) began as a critique of how jurisprudence was taught at an introductory level. ${ }^{4}$ However, CLS also focuses on making explicit the foundational political, sociological, and anthropological assumptions and discursive practices that underlie classical liberal approaches to American legal theory and rethinking these assumptions and practices. In this way, Critical Legal Studies is a pedagogical and scholarly propaedeutic project that can serve as a model for scholars of Islamic legal studies. This is a precise balancing act. On the one hand, they most pose critical questions to their audience about the present moment: about political instabilities in the category of religion in multicultural liberal societies, about commonplace assumptions of what the law is and how it works, and about the alarming rise of Islamophobic politics and its supporting lies, myths, and innuendo. On the other, they must keep in mind the goal of introducing audiences to different 
perspectives than their own, to different modes of thought and practice from which vantage they can look again on our world. Like in religious studies in general and other fields, a propaedeutic of Islamic legal studies in North America explores other perspectives and reflects on realities present to us. Public scholars can then begin considering a propaedeutic of Islamic legal studies thinking about modern power, authority, and legitimation.

\section{Liberalism, Multiculturalism, and Anxieties of Difference}

In religious studies, Islamic studies, and other fields, scholars who work on Islamic law do so in a particularly public context. Scholars in this field and others have reflected on liberal societies' dynamics of inclusion and exclusion and on its particular problems of tolerance. ${ }^{5}$ Because the law and legal discourses are central both to liberalism and to Islam, scholars have to consider the potential for conflict between different conceptions the law and legal practices, and the implications of those conflicts for the idea of tolerance. However, scholars of Islamic legal studies cannot only concern themselves with using theory to ask audiences deeper questions about liberalism. The field also needs to respond to the growth of Islamophobic political rhetoric amid the ascent of the anti-immigrant far right. Such rhetoric often suggests that Muslims are somehow legally different from the majority through vilifying ritual, dietary, and sumptuary differences. Political campaigns and public discourse against Muslims also connect to deeper patterns of racism and structural exclusion in US society. ${ }^{6}$ These manifestations of Islamophobia arise from tensions within liberal societies, much as these forces seem apart from the high-minded and inclusive liberalisms.

Particular North American ideas and practices of pluralism form the background in which Islamic legal studies works today, and these ideas and practices bear consideration in a propaedeutics of Islamic legal thought. Superficially, social multiculturalism and political liberalism in this context might seem to better accommodate people who follow Islamic legal traditions than many Western alternatives. ${ }^{7}$ First, broadly speaking, liberalism in the US prizes individual and group autonomy and the freedom of religion, in seeming contrast to government restriction of the publicity of religion or delimiting individual and communal relations through religious identification. ${ }^{8}$ In addition, the US has a relatively light sense of a proprietary culture that could promote a cultural policy enforced against people living in the country. ${ }^{9}$ In this, the social and political pressures Muslims face would seem to have little to do with Anglo-North American pluralism, and these pressures in turn might seem to only have theoretical pertinence to 
Islamic legal studies as done by academic scholars based there. However, in public presentations and in the classroom, scholars of Islamic legal studies often have to confront particular anxieties of difference that are structured by these norms of pluralism that at first might appear so tolerant.

Specifically, to do propaedeutic work, scholars of Islamic legal studies need to consider how citizens and institutions in liberal polities understand and relate to people and communities who are seen to be something other than liberal. Liberalism has at its heart a tension between a freedom that allows individuals maximum latitude in self-fashioning and community formation, and one that implicitly prescribes the fullest and most fulfilling enjoyment of that latitude. Jeffrey Stout, among others, identifies a collection of tensions in Anglo-American liberalism: the liberal state's supposed religious neutrality often precludes consideration of moral and religious reasoning because liberal conceptions of bare, universal, and neutral political rationality tend to exclude the many particular non-liberal forms of reasoning. ${ }^{10}$ To simplify, liberals in Anglo North America have difficulty conceiving of how or why others may choose to be other than liberal. Within feminist thought, this conflict is realized in the essay "Is Multiculturalism Bad for Women?" and its aftermath. ${ }^{11}$ According to the essay, minority communities such as Muslims are considered to have autonomy and interests promoted through multiculturalism. However, such community autonomy, understood as the desire to preserve patriarchal tradition, is in potential conflict with ideas of personal autonomy promoted in classical liberal feminism. The question then follows: if liberal multicultural societies read Muslim legal and ethical practice as, in broad strokes, patriarchal, do these practices work against the norms of equality these societies seek to promote, and to what extent are such concerns social, political, or even legal?

The nature and expression of Islamic law is often at issue in legal cases under laws shaped by multicultural concerns for individual and group autonomy, as well as liberal norms about religion in the public and private sphere. For example, some courts in the US and Canada have allowed for religious arbitration, often in the realm of family law. Some cases have required courts and governments to recognize particular religious bodies as competent for these processes. Family courts in Ontario had authorized Catholic and Jewish bodies to arbitrate divorce and custody cases. However, in 2005, the prospect of including Muslim bodies to do the same work provoked intense controversy about the state's obligations to protect women's rights and questions about whether and how Muslim women 
were capable of exercising those rights fully. The provincial government ultimately discontinued religious arbitration without formally investigating whether arbitrators of any particular tradition promoted equitable outcomes for women. ${ }^{12}$ Indeed, these controversies, in and of themselves, have not defined what is equitable and what is not, or how equitability and religious freedom relate. While Ontario does not permit religious arbitration as it used to, the practice has grown in the US, which suggests that religious, legal, and political authority continue to overlap and intersect. However, despite its commitments to religious freedom and the persistence of a laissez-faire multiculturalism, in North America, the public do not ask the same questions or raise the same concerns about religious freedom or multiculturalism when other religious traditions are seen to be at issue.

Liberalism's concern for the rule of law and its anxieties of difference are often in the background when Islamophobic panics arise. ${ }^{13}$ Accordingly, contemporary Islamophobia represents more than the protean anti-immigrant sentiment, which in American history periodically arises, dissipates, and reemerges. ${ }^{14}$ Anxieties around legal-religious difference rather concern the nature of the liberal-multicultural constitution and the state's ability to determine and enforce it in law. In this decade, various US legislatures have considered bans on "shari' ${ }^{-} a$ ", ${ }^{15}$ with some coming into effect at the state level. ${ }^{16}$ It is questionable what, if anything, such bans change about existing laws or how any legislature could prohibit its successors from making any law in the future. Lee Ann Bambach argues these legislative measures are unconstitutional and serve no practical legal purpose. ${ }^{17}$ However, they do serve to demonize Muslims. Newt Gingrich suggested that the US should deport Muslims if they "believed" in the sharīa a. ${ }^{18}$ While scholars of Islamic studies should respond to any form of Islamophobia, it should be noted here how Gingrich conceives of the law as a belief, potentially disqualifying people from their homes. He seems to be saying that that people can be legal aliens to a country simply in their mental or intellectual state, which is a much more intimate register of who is an American than family structure. It is difficult to imagine US sharīa bans amounting to much that would substantially worsen Muslims' lives, especially in comparison with US wars in the Muslim world and the broader security state. Moreover, Gingrich's inquisitorial thinking may be more extreme than even the rising far right political movements in the West might embrace. However, it marks the rhetorical spaces in which law and legal difference bring up anxieties of fit within liberalism. Whether or not scholars in Islamic legal studies choose 
to address these anxieties explicitly, the latter do set the discursive terrain in which the field has its public salience.

North America Islamophobia may seem to be a right-wing phenomenon driven by popular prejudice, but in fact, Islamophobia highlights significant anxieties of legal difference within liberalism. To begin with, although it is indisputable that Islamophobia has been a mainstay of the modern far-right, Muslims have been consistently viewed the most negatively among religious groups. ${ }^{19}$ Underscoring this point from another direction, more than four fifths of Americans believe that Muslims face significant discrimination, and more than half say it is "a lot" of discrimination. ${ }^{20}$ The reasons for this bias are not immediately obvious. Muslims are also not "objectively" more outside of the American mainstream than Hindus, Buddhists, or people of other traditions. Indeed, Hinduism and Buddhism do not share a common genealogy with Christianity as Islam does. On the one hand, "terrorism" might be said to be a driver of Islamophobia. However, "terrorist" violence lacks a straightforward definition, and media, scholars, and the public scrutinize the supposed motives of Muslim perpetrators of violence in ways that they do not look for or ask about reasons from non-Muslims. ${ }^{21}$ In a way, "terrorism" is a product of Islamophobia as much as Islamophobia is a product of terrorism. I suggest that what is "different" about Islam is that it is thought to present ideas of a fundamentally different political order than liberalism. Islamic law does form the ostensible basis of government in many states. As such, observant Muslims can represent not only a people who are living in other than liberal ways, but those whose very practice can represent the possibility of coercion and overwhelming force the law is assumed to monopolize in modern politics. Scholars of Islamic legal studies not only need to be wary of this conceptual agglomeration, they need to interrogate it.

\section{Islamic Legal Studies: Disentangling Law, State, and Religion}

Scholars of Islamic legal studies can do important propaedeutic work when they denaturalize commonplace assumptions about what law is how it relates to the state. Not all work in the field in recent decades specifically addresses modern institutions, and the assumptions on which they are based, from alternative Islamic premodern or modern perspectives. However, politically-engaged teachers and scholars can address broader audiences in ways that make the familiar strange and the strange more familiar. In recent years, Wael Hallaq's critique has stood out for how it argues against popular and scholarly interpretations of Islamic legalism as rigid and uncritical 
repetition of the past. He and others have also used Islamic legal histories to highlight the novelty and coercion of such modern familiarities as codified law, law enforcement, and state sovereignty itself. Alongside Hallaq's textual scholarship, Talal Asad provides anthropological and genealogical critiques of the modernizing processes ostensibly distinguishing religion from the law but actually interconnecting the two. Asad also expands the focus of the law and legal thinking to embodied practices and beyond state and religious educational institutions.

The propaedeutics I propose emerges from the broad history of the field of scholarship on Islamic law and the state. Not all of this scholarship concerns the modern state specifically or the ways discourses of Islamic law have changed within Muslim societies and outside them. ${ }^{22}$ However, if propaedeutics is to do its job of introducing a field of research or knowledge, it should trace the broad outlines of that field and show the major ways it is organized. Scholars of Islamic studies have been interested in the political since the beginning of the academic discipline in the West. Max Weber believed Islam, particularly its legal traditions, exhibited a style of reasoning anathema to capitalist modernity. ${ }^{23}$ Joseph Schacht, who brought Islamic legal studies to the United States in the mid-twentieth century, concluded that the law lacked a systematic reasoning, could not account for how to consistently interpret sources, and even could not consistently claim the validity of those sources. ${ }^{24}$ As a result, scholars such as Montgomery Watt tended to view Islamic legal thought as a theoretical simplification of complex socio-political realities and only interesting to the extent that it could inform us about the "real" world. ${ }^{25}$ Scholars such as Patricia Crone promoted interest in the caliphate (khiläfa), a topic of juristic discourse, which presents a way to track legal theory with political histories. ${ }^{26}$ The anthropologist Brinkley Messick considered how the modern state transformed the role of legal documentation in the lives of ordinary believers. ${ }^{27}$ Sherman Jackson discusses the political implications of legal discourses themselves, arguing that maintaining cohesion within juridical traditions could be considered constitutional governance. ${ }^{28}$ This field is expansive, and importantly, its variety illustrates that the law can be fully realized without consideration of the state and that the two domains do not necessarily connect in the same way in all contexts. It is to this broad field that the propaedeutic here takes two agendas of approach.

Wael Hallaq both critiques long-repeated caricatures of Islamic legalism and rethinks modern commonplaces from the perspectives of these 
traditions. Early in his career, Hallaq made the case that ijtihād-independent and adaptive reasoning from authoritative sources-has sustained Islamic legal thought throughout its history. He argues against a decline narrative according to which, after a brief period of creative flourishing in its formative period, Islamic jurisprudence turned to hidebound imitative traditionalism, namely that the "gates of ijtihäd" had effectively closed. Such a story neatly aligns with orientalist stereotypes of an Islamic worldview uncritically devoted to the past. ${ }^{29}$ More recently, Hallaq has written histories of legal thought over the long term and critiqued the ways that imperial and national power has replaced autonomy and authority with coercion. He argues that European imperials were the first to codify Islamic law, taking power unto themselves that had existed disseminated among jurisconsults, judges, and scholars, and ordinary people. This process greatly diminished the spaces and practices for interpersonal and communal negotiations. ${ }^{30}$ Hallaq finds that, far from being a specter haunting the West, the sharīa does not practically exist anymore, even in the Muslim world, ${ }^{31}$ and moreover, it cannot without a wholesale disassembly of the modern state and a rethinking of liberal subjectivity. ${ }^{32}$ Postcolonial scholars have taken work on Islamic law into these two avenues of political and ethical critical critique.

Asad attends to embodied practices and modes of authority in Muslim legal traditions to reflect critically on political liberalism and secularism. As an anthropologist, Asad considers the law beyond judicial and academic institutions. For him, Muslim parents and friends participate in authority over others alongside scholars, mystics, and jurists. Asad does not understand Islamic law or religion to extend to everything Muslims say and do, but restricts it to when they teach other through and about the authoritative past. ${ }^{33}$ Asad thinks about the conceptual domains of the law, authority, and power more expansively than only as official regulation and coercion. If scholars consider authority at work in ordinary instruction and disagreement about daily ritual, for example, they can see the legal domain as an everyday domain in which not only the exceptionally learned and empowered exercise authority. Those attuned to legal discourses need to be ready to listen to everyday discussions of dress, deportment, ritual, and commerce among people in a variety of different situations rather than only among specialists. Asad's other critical contribution consists in his critique of modern assumptions about the inherent distinctions and connections among the law, the state, and religion. Asad argues that far from keeping 
religion out of politics, secularism assures that the division between the religious and the non-religious, and the public and the private, intermittently comes into question and often signals the development of state power. ${ }^{34}$ Asad and his interlocutors observe how the shari'a becomes the subject of modernizing states, how states promote implementation of and supervision over Islamic law to guarantee family stability, women's rights, free speech, and the protection of religious norms. ${ }^{35}$ States' mechanisms and claimed purposes may vary and even appear opposite, but the processes invariably result in the routinization of state power.

\section{Critique and Propaedeutic Risk}

Scholars of Islamic legal studies need to teach and represent their field in ways that foreground the critical insights explored above and do not oversimplify the subject matter. As such, the critical scholarship above presents propaedeutic risks. Teachers and scholars facing the public need to assess how to make propaedeutic interventions. They should ask how their work introduces the scholarly field they are talking about, how they provide comprehensible and orderly information in terms of which listeners can understand more and learn further. However, when scholars choose to counter negative prejudices with positive oversimplifications to try to direct attention away from controversial topics, they can actually prevent audiences from engaging the material in more complex ways later on. The critical scholars above intervene in public discourse to counter myths and to encourage consideration of other possibilities in history and the present. However, their work presents propaedeutic risks scholars need to understand and negotiate. As scholars engaged in propaedeutics try to dissuade audiences from seeing the sharīa as rigid and domineering, they need to be careful not to portray legal thought as unbound, anomalous, as present in individual cognition without consequence in the real world. These are unhelpful suggestions in a context like North America with personalized and liberal conceptions of private moral-spiritual religion. They can also echo orientalist caricatures of earlier scholarship.

In their public work and teaching, scholars of Islamic legal studies need to counter misperceptions, particularly Islamophobia, conscious of propaedeutic risk. An introduction to any subject requires simplification, however, the best kinds of propaedeutic begin with simplicities while giving a sense of the order by which students can understand complexity in greater detail. Propaedeutics should give a sense of what kinds of questions 
can be asked about a field, and why they matter. Scholars thus need to ask themselves how can they teach in ways that inspire curiosity, invite responsible comparison and contrast, and reflection on the lived world of the moment. Islamophobia is so pervasive in North America-and powerful political actors so willing to exploit it and enact grievous harm against Muslims-that Islamicists can feel as they have little other public task than disabusing people of it. However, when they introduce complex and controversial topics, they need to do so in ways that do not flatten living and historical traditions or foreclose challenging discussions. For example, if they use the simplistic and linguistically incorrect formula "Islam means peace" to counter the Islamophobic imaginary of the menacing, interminable jihad, they discourage audiences from reflecting further. They foreclose such questions as: How does jihad compare to other religious and non-religious calls to war? How does the often-overemphasized secondary meaning of "inner jihad" suggest believers can fashion themselves through combat? How can they understand jihad within history, in which Muslim powers have ruled over and interacted with diverse populations peacefully? They need to be careful of Islamophobia's falsehoods and misperceptions, however, they should provide truth and make critique with the purpose of promoting rather than restricting further inquiry.

When they counter the Islamophobic caricatures of a domineering and coercive shari ${ }^{-c} a$, they must not replace these misunderstandings with concepts of Islamic legal practice and theory that overly privatized and overly intellectual. If they emphasize that Islamic law developed without state-authored codes and law enforcement in the modern sense, they need to be careful not to suggest the tradition of fiqh had no material effect in the "real world". When scholars describe the unenforced authority of the fatwa, they can unintentionally convey the idea that it is "just an opinion", and that curious or self-interested fatwa-seekers may simply get second and third opinions without limit. It is not that North American audiences have no ideas about moral or political authority, it is rather that religious observance in this context tends to be understood as private, personal, and freely chosen. An independent, spiritually sovereign subject chooses to follow a specific tradition, and the content of what following that tradition means. If scholars allowed their students or audiences to understand Islamic law as an idea that is not enforced with no formal hierarchy of jurists, they might conclude that Islamic law consists in options that a Muslim who sought legal counsel could simply choose to follow or not. They cannot present 
Hallaq and Asad's critiques of liberalism and its secular-private-interior conceptions of religion if they unwittingly reinforce them (or leave them unaddressed) because they tried to present Islamic law as radically different from its familiar Islamophobic caricature as domineering and suppressive. They need to foreground often-unstated assumptions about the nature, place, and constitution of religion in our propaedeutics of Islamic law.

Modern scholars also need to be aware of the history of Islamic legal studies and be careful not to echo orientalists' dismissal of legal thought. It is important to impart that Islamic jurisprudence does not have a formal ecclesial hierarchy. Premodern jurists did not think the sharīa resided in authoritative codes administrated by states. Jurists have argued that different people are qualified to undertake different kinds of legal reasoning: some can only imitatively follow precedent while others can exert ijtihād and engage authoritative sources directly. ${ }^{36}$ Jurists do in fact cite the famous hadith that the correct ijtihād is worth two merits and the incorrect worth one, which leaves this highest grade of legal interpreter room to think in good faith. ${ }^{37}$ However, though modern scholars should stress the independence and relative freedom in legal reasoning, they should not suggest legal thought is anomalous-as in Max Weber's well-known stereotype of Kadijustiz, the judge sitting under a tree dispensing arbitrary opinion. ${ }^{38}$ Without codes and the administrative infrastructure on which modern states depend, audiences might conclude Islamic law lacked consequence in the real world, that it is less "real" in authority and basis.

A similar problem affects the work of a pioneer of Islamic legal studies. Joseph Schacht claimed that Hadith literature represented just such an adhoc and instrumentalist fabrication by jurists seeking to advance their own positions or provide people the opinions that they wanted themselves. ${ }^{39}$ Contemporary scholarship has moved away from Schacht and Weber's characterizations of Islamic law as anomalous, unsystematic, potentially despotic or fictional. However, audiences might come away with judgments like these if scholars overcorrect the stereotypes of a rigid and constrictive traditionalism that forces the harsh judgments of the past on its subjects and instead discuss jurists' freedom, creativity, and adaptability to changing circumstances. Teaching scholars may suggest these stereotypes even if they do not want to. They rather result from not only well-known (if contradictory) orientalisms but also from discussions of the law that are overly abstract and disconnected from its ethical registers and social context. 


\section{Counsel and Jurisdiction: Propaedeutics of Practice in Islamic Legal Thought}

Scholars need to think not only about the nature of the law as such, but also about distinctive legal practices and in relationships among people constituted through the law. Law in contemporary North America and in modern and premodern Islamic contexts involves the seeking and giving of counsel. It also assumes a jurisdiction, a notion of to whom the law speaks, how it speaks to them, and within what boundaries. A focus on counsel and jurisdiction should not replace broader inquiries about the nature of the law itself or how it has changed with the rise of modern power. Rather, a propaedeutic observing a legal concept in practice helps illustrate non-coercion and non-homogenization scholars describe. The propaedeutic here builds from the anthropological critiques of Hussein Ali Agrama and Saba Mahmood, who observe jurisprudence at work as well as the genealogies of legal change in history. I do not suggest here that anthropology in general, or Asadian anthropology in specific, has a special propaedeutic value over and above other ways of doing Islamic legal studies. It is rather that work such as Agrama and Mahmood's illustrates unfamiliar situations and encourages us to reflect back on our own. I provide some illustrations of how their analysis helps us understand non-ethnographic propaedeutic sources as well. Scholars of Islamic legal studies also need to think about the propaedeutics within the traditions they study, and the potentials for propaedeutics the traditions present.

Islamic jurists thought about the orders inherent in their knowledge of their own traditions, and their work has propaedeutic value even when it is addressed to situations very different from those familiar to the audiences of modern academic scholars. When scholars introduce audiences to subjects that are not familiar to them, they often begin with what they assume the audience might think or understand. ${ }^{40}$ However, introductory students and broader publics need to understand that central concerns of Islamic law include topics foreign to major parts of the modern world, even to the state laws of Muslim-majority countries: for example, ritual. I have found many audiences surprised that prescriptions of procedures for specific actions of religious significance is a concern for something called "law". Ritual presents a propaedeutic opportunity to present an order of legal knowledge shaped around different concerns. However, it is also an opportunity to invite comparison with concepts many audiences will understand have legal significance such as intention (niyya), age of majority (bulügh), and even 
exemplary precedent (sunna). ${ }^{41}$ Scholars who want to use the concept of ritual law for a propaedeutic exercise should consider a source for how to make this example.

On this point, I have found that the legal compendium (mukhtașar) has important propaedeutic value. Its organization and proportions attest to the importance of ritual. For example, there is the Bidayyat al-mujtahid (The Jurist's Primer ${ }^{42}$ by Abū-l Walīd ibn Rushd (1126-1198) ${ }_{{ }^{43}}$ a comprehensive work by one of the most well-known premodern Muslim thinkers, which crucially, is available in English. In order, this compendium describes the purification required for many rituals (tahära), ${ }^{44}$ then the obligatory daily prayers (salat $),{ }^{45}$ treatment of the dead ${ }^{46}$ the payment of alms $(z a k \bar{a} t),{ }^{47}$ fasting $(s i y \bar{a} m),{ }^{48}$ and the Hajj. Ibn Rushd, like others, prioritizes those matters that are most common in observant Muslims' lives, that Muslims learn about first in their lives. Then the jurist describes what is part of a "normal" year for an observant Muslim. As the text goes on, it details what is important for everyone once in their lifetime; and subsequently what is less and less important for all individuals, dealing at the end with criminal ( $h u d \bar{u} d$ ) punishments. Scholars of Islamic legal studies can make the propaedeutic point that what is considered central to the law in modern liberal and non-liberal understandings, criminality, is for fiqh-jurisprudence an extreme case. In fact, the word hudūd refers to limits. Public and academic audiences can be introduced to a world of legal practice and thought that is rather concerned with how to develop and maintain a full religious life. The law does guard the peripheries of what is "normal", but throughout, it also establishes guidelines.

Agrama explores legal counsel as the seeking of authoritative guidance and as a practice of care of the self. Agrama contrasts two legal processes in contemporary Egypt: the rendering of judgment in a state law court and the seeking of a fatwa from a council of muftis. In the latter case, questioners (mustaftīs) ask muftis for considered legal opinion on precise matters of ritual, moral problems, and questions of rights and responsibilities in marriage, divorce, child custody, and inheritance. No state authority enforces these fatwas; muftis rely on no ecclesial hierarchy that places them "over" mustaftìs. However, Agrama finds that the questioners tend to take the fatwas they receive very seriously, even when their interests are not favored or their actions are judged incorrect. Agrama suggests that mustaftìs look to muftis as guides, as people who know the way in front of them. Similarly, Agrama's concept of authority as guidance detaches it somewhat from 
anxieties of power and dominion. A fatwa does not assert one person's right to guide another in any journey. A fatwa does not claim the authority of the sharīa $-a$ path for all in divine favor-as such. However, it does claim directive authority for a specific point of questioning. This point is arrived at not only by the mufti's discernment, but also a process of self-examination on the part of the mustafti. Agrama interprets such self-examination in light of the ethics explored by Foucault. ${ }^{49}$ Later in his career, that foremost theorist of power began to ask about self-care and self-fashioning in voluntary disciplinary relationships, such in Christian monastic contexts. ${ }^{50}$ Agrama's ethnography gives ethnographic illustration to guiding authority at work in contemporary life.

My teaching experience suggests the film Justice à Agadez vividly illustrates the complexities of legal authority apart from the work of the state. ${ }^{51}$ Set in rural Niger, the documentary follows a $q \bar{a} d \bar{\imath} \bar{\imath}$ whose judgments litigants seek outside official courts. The settings are modest; much of the action takes place in homes, devoid of the architecture of power and permanence associated with courthouses. The $q \bar{a} d \bar{l}$ does not use private chambers or rely on a uniformed court service to enforce order and propriety. However, litigants take his judgments seriously. In one scene, the qā $\bar{d} \bar{\imath}$ confronts claimants with two contradictory accounts of stolen goods, requests the contestants take oaths that they are telling the truth, and reminds them of the grave religious importance of the act. The accused thief cannot examine himself and swear his innocence, though no temporal penalty for perjury or false reporting appears to apply. The $q \bar{a} d \bar{\imath}$ also talks a disputing married couple through several complaints against one another, illustrating the concept of shari ${ }^{`} a$ as facilitating affairs as opposed to individual judgments of permission and prohibition. ${ }^{52}$ Far from dismissing the couple's problems and telling them to work to stay together, the $q \bar{a} d \bar{i}$ gives precise ethical instructions to each and delineates grounds for divorce. Agrama similarly finds that muftis inquire of those questioners who are concerned that they or others have done something seriously wrong if there are mitigating circumstances or misunderstandings that may affect the case. The point here is not that muftis and $q \bar{a} d \bar{i}$ s express concern or leniency against the stereotype of the literal-minded and punitive tendencies of Islamic law. It is rather to illustrate that counsel, through fatwas and judgments, is authoritative for those seeking guidance for themselves and in social relations. Without state coercion that forces people to interact with legal systems, these people are a voluntary sample of those to whom the law speaks. 
A propaedeutic of jurisdiction emerges from Saba Mahmood's investigation of religious plurality and the minority question. Much of the scholarly ijtihād debate and popular discourses of Islamic law concern how Islamic traditions account for internal and external difference. These are questions of jurisdiction: of how and to whom the law "speaks". In precolonial Muslim contexts, jurisdiction was not geographic but personal. Muslims might follow different legal prescriptions from others intimately connected to them. ${ }^{53}$ In many cities, large communities of non-Muslims lived in close proximity with most of what is called "Islamic law" not applying to them. Mahmood describes the late-Ottoman legal reforms that attempted to change this and consolidate legal authority and the responsibility to manage non-Muslim minorities to the imperial state. ${ }^{54}$ In the contemporary moment, Mahmood argues that secularism in Egypt has not protected minority rights so much as made personal commitment and communal belonging subjects of domestic and international politics. ${ }^{55}$ Stories of abduction and forced conversion that circulate in contemporary Egyptian media are premised upon internally-homogeneous Christian and Muslim communities subject to two personal-status codes supervised by the state. Subsequently, conversion, whether forced or willing, is a matter of communal politics, with the state deciding who gains and loses and how "communal integrity" can be protected. Mahmood argues that this arrangement renders women particularly vulnerable as movement between communities can be read as coercion irrespective of what women themselves say. ${ }^{56}$ While the state's marking of religious jurisdictions is supposed to protect women's rights, all it has secured is sovereign authority.

While mainly focused on the present moment, Mahmood's argument can help explore personal jurisdiction in premodern Islamic legal thought. Taqi al-Din Ahmad ibn Taymiyya (1263-1328) $)^{57}$ wrote Kitāb iqtiḍā alșirăt al-mustaqìm mukhālafat așhāb al-jaḥim (The Book of Discerning the Straight Path from the Companions of Hell) to guide Muslims as they negotiated the mixed traffic of multifaith Damascus.$^{58}$ Ibn Taymiyya says it is permissible for Muslims to attend non-Muslims' market-days. However, they need to attend to particular ethical hazards. Such environmental risks include Christian liturgical music, which can excite the emotions and incline the senses toward the other community's rites. Ibn Taymiyya finds such an environment particularly risky for women for this reason. The jurist says that though the market is a place to pursue one's own purposes, and to make instrumentalist calculations of utility, the first generations of Muslims established their standard of behavior as the greater good. 
Muslims in others' space need to comport themselves conscious of this standard in recollection of their forebears even in the inclination of their senses. Agrama and Mahmood understand practices like these through Foucauldian self-care and an Aristotelian habitus respectively. ${ }^{59}$ However, Ibn Taymiyya's concerns also illustrate the framework of personal jurisdictions. The source shows the premodern Islamic convivencia not as an affirmation of diversity, but suggests ways that traditionalists try to navigate a world of others without designs on coercive power or politicizing difference in the modern sense. ${ }^{60}$ Ibn Taymiyya's sensibilities do not need to be our audience's own to teach us that.

\section{Conclusion}

The propaedeutic presented here asks us to consider our work in a context in which misinformation and misunderstanding thrive. I suggest scholars of Islamic legal studies approach their audiences not dismissive of the fearful discourses that surround Islam and particularly Islamic legal traditions as only the result of one-sided propaganda, but that these reflect fissures and anxieties within multicultural liberalism in North America. Recent scholarship has explored Islamic legal difference not as an alternative to this order as such, but a perspective from which to consider how difference can cohabit and authoritative precedent inform personal and social life. I suggest they think with this scholarship aware of the propaedeutic risk of describing plurality and non-coercion being heard as private morality and freedom of conscience. A fuller introduction to Islamic jurisprudence includes comparing and contrasting concepts constitutive of that tradition and familiar to the modern world. I have suggested ways that considering counsel and jurisdiction illuminate accessible and familiar sources. Presenting these concepts in practice also contributes to a fuller picture of how Islamic legal traditions inspire people to consider and debate correct observance without the imposition of codified law or the presence of law enforcement, and with a consciousness of difference strikingly different from one more familiar to North Americans.

To conclude, I want to consider a potential objection to propaedeutics in scholarship. It can be objected that scholars should principally concern themselves with research, which aims to carefully and precisely inform their colleagues and diligent students, and our work should not be dictated by the popular politics that dictate so much else. From this, teaching is separate and secondary, and in the classroom, scholars should only strive to present the clearest and simplest picture that is true to their sources 
and then leave students to draw their own conclusions about their world. I would respond to the objection that the propaedeutical approach I am suggesting here is not a dissent from traditional scholarly or pedagogical practice. It is rather a thought about how to teach and research while commited to the context in which scholars and students live. In this context, introduction to and explanation of Islmaic legal thought, histories, and practices are in high demand, and they are also highly scrutinized. Scholars have not chosen this situation, but in it, they must reflect on how to prepare listeners for difference and complexity when they are hearing so much and such mendacious oversimplification.

\section{Endnotes}

1. Consider Hegel's propaedeutic. While rector of the Nuremberg Gymnasium from 1808-11, the philosopher envisioned a curriculum of elementary through high-school education that would prepare boys to learn philosophical self-awareness. Editors of the text argue that the Propaedeutic is an early version of his Encyclopedia written as outline of instruction. As such, Hegel's thought connects to both the eighteenth-century encyclopedic tradition and modern philosophies of education. The system also has meaning for Hegel in that a child matures as humanity comes to greater self-awareness and more perfect freedom through history. In this sense, propaedeutics concern both an epistemological organon and inculcating awareness of a maturing person's social, historical, and political situation. Georg Wilhelm Friedrich Hegel, The Philosophical Propaedeutic, trans. A.V. Miller (Oxford: Basil Blackwell, 1986).

2. Ebrahim Moosa, Ghazali and the Poetics of Imagination (Chapel Hill: University of North Carolina Press, 2005); Eric Ormsby, Ghazali: The Revival of Islam (Oxford: Oneworld, 2008); W. Montgomery Watt, The Faith and Practice of al-Ghazālī (London: G. Allen and Unwin, 1953).

3. Al-Ghazali believes that people have an upper limit to their knowledge, and most people will struggle to understand even the exoteric knowledges. Such people should not push themselves into what they cannot understand and should trust that God provides for all intellects and would not expect more than they are capable of. Abu Hamid al-Ghazali, Ihyya' 'ulüm al-dīn [The Revival of Religious Knowledge], 2 vols. (Cairo: Dār al-Salām li-l-Tibā'a wa-lNashr wa-1-Tawzì wa-1-Tarjama, 2003), 1:26-40. 
4. In sum, see Robert W. Gordon, "Unfreezing Legal Reality: Critical Approaches to Law," Florida State University Law Review 15, no. 2 (1987): 195-220; Roberto Mangabeira Unger, The Critical Legal Studies Movement: Another Time, A Greater Task (London: Verso, 2015).

5. Consider Wendy Brown, Regulating Aversion: Tolerance in the Age of Identity and Empire (Princeton: Princeton University Press, 2008).

6. Megan Goodwin, "Unmasking Islamophobia: Anti-Muslim Hostility and/as White Supremacy," Journal of the American Academy of Religion 88, no. 2 (2020): 354-386.

7. Consider Mayanthi L. Fernando, The Republic Unsettled: Muslim French and the Contradictions of Secularism (Durham: Duke University Press, 2014); Joan Wallach Scott, The Politics of the Veil (Princeton: Princeton University Press, 2007). Olivier Roy argues that observant Muslim practice does not challenge French traditions of laïcité as such, but the belief that they do speaks to historical ambiguities within the modern republic. Olivier Roy, Secularism Confronts Islam (New York: Columbia University Press, 2007).

8. The colonial heritage of personal-status law has left an enduring legacy on intercommunal relations in South Asia; see Rajeev Bhargava, ed., Secularism and its Critics (Delhi: Oxford University Press, 1999). I thank Francesca Chubb-Confer for this reference.

9. Many European countries and Quebec have banned various forms of women's clothing. “The Islamic Veil Across Europe," BBC, May 31, 2018, https:// www.bbc.com/news/world-europe-13038095; Ashifa Kassam, "Quebec Passes Law Banning Facial Coverings in Public," The Guardian, October 18, 2017, https:/www.theguardian.com/world/2017/oct/18/quebec-passes-lawbanning-muslims-from-wearing-face-coverings-in-public.

10. Jeffrey Stout, Democracy and Tradition (Princeton: Princeton University Press, 2004), 63-92. For one response to the Rawlsian liberal social contract from Islamic legal thought, see Andrew F. March, "Islamic Foundations for a Social Contract in non-Muslim Liberal Democracies," American Political Science Review 101 (2007): 235-52.

11. Susan Moller Okin, Is Multiculturalism Bad for Women?, with respondents, ed. Joshua Cohen, Matthew Howard, and Martha C. Nussbaum (Princeton: Princeton University Press, 1999).

12. "Ontario Premier Rejects use of Shariah Law", $C B C$, September 9, 2005, https://www.cbc.ca/news/canada/ontario-premier-rejects-use-of-shariah-law-1.523122; Debating Sharī'a: Islam, Gender Politics, and Family Law Arbitration, ed. Anna C. Korteweg and Jennifer A. Selby (Toronto: University of Toronto Press, 2012); for analysis of the controversy in terms of culture, multiculturalism, and progress in parallel to above, see Sherene H. Razack, “The 'Sharia Law Debate' in Ontario: The Modernity/Premodernity 
Distinction in Legal Efforts to Protect Women from Culture," Feminist Legal Studies 15 (2007): 3-32.

13. In a critical investigation, Khaled Beydoun concludes that though security discourses have amplified Islamophobia, its roots extend through discrimination against immigrants from Asia and the enslaving of African-Americans; see his American Islamophobia: Understanding the Roots and Rise of Fear (Oakland: University of California Press, 2018).

14. To be sure, this nativism consistently excludes indigenous native peoples and African-Americans. However, its conceptions of race, language, and culture shift dramatically: Walter Benn Michaels, Our America: Nativism, Modernism, and Pluralism (Durham: Duke University Press, 1995).

15. On the discourse on and practice of "sharia" in the West, see Maurtis S. Berger, "Understanding Sharia in the West," Journal of Law, Religion, and State 6 no. 2-3 (2018): 236-73. I would only contest the author's framing of the issues as "cultural". Whatever the framework used, what Muslims want and are doing is always a controversial topic in contemporary Western countries.

16. Katherine Lemons and Joshua Chambers-Leston, "Rule of Law: Sharia Panic and the US Constitution in the House of Representatives," Cultural Studies 28, no. 5 (2014): 1048-77; "Anti-Sharia Bills in the United States," Hatewatch, Southern Poverty Law Center, published February 5, 2018, http://www. splcenter.org/hatewatch/2018/02/05/anti-sharia-law-bills-united-states.

17. Lee Ann Bambach, "Save Us From 'Save Our State': Anti-Sharia Legislative Efforts Across the United States and Their Impact," Journal of Islamic Law and Culture 13, no. 1 (2011): 72-88.

18. Melissa Etehad, "After Nice, Newt Gingrich Wants to 'Test' Every Muslim In the U.S. and Deport Sharia Believers," Washington Post, July 15, 2016, https:// www.washingtonpost.com/news/morning-mix/wp/2016/07/15/after-nicenewt-gingrich-wants-to-test-every-american-muslim-and-deport-thosewho-believe-in-sharia/.

19. Pew Research Center, "Americans Express Increasingly Warm Feelings Toward Religious Groups," February 15, 2017, https://www.pewforum. org/2017/02/15/americans-express-increasingly-warm-feelings-toward-religious-groups/.

20. David Masci, "Many Americans See Religious Discrimination in U.S. - Especially Against Muslims," Pew Research Center, May 17, 2019, https://www. pewresearch.org/fact-tank/2019/05/17/many-americans-see-religious-discrimination-in-u-s-especially-against-muslims.

21. In sum, see Talal Asad, On Suicide Bombing (New York: Columbia University Press, 2007).

22. For an overview of Islamic legal studies and the state, see Mohammad Fadel, "State and Sharīa," in The Ashgate Research Companion to Islamic Law, eds. 
Rudolph Peters and Peri Bearman, 93-107 (Farnham, Surrey: Ashgate, 2014). I thank Mariam Sheibani for this reference.

23. Weber says that Islam, in contrast to Protestantism, places no importance in believers' manifesting their predetermined salvation through prosperity and the ordering of their lives. Thus, for Muslims, "there were no consequences for the rationalization of life, for there was no religious reward for them." Max Weber, The Protestant Ethic and the Spirit of Capitalism, trans. Talcott Parsons (New York: Scribner's Sons, 1958), 227 n. 36. Consider Wolfgang Schlucter, "Hindrances to Modernity: Max Weber on Islam" in Max Weber and Islam, eds. Toby E. Huff and Wolfgang Schluchter (New Brunswick, NJ: Transaction, 1999), 53-138; Patricia Crone, "Weber, Islamic Law, and the Rise of Capitalism," in Max Weber and Islam.

24. Joseph Schacht, An Introduction to Islamic Law (Oxford: Oxford University Press, 1964).

25. Montgomery Watt, Islamic Political Thought (Edinburgh: Edinburgh University Press, 1968).

26. Patricia Crone and Martin Hinds, God's Caliph: Religious Authority in the First Centuries of Islam (Cambridge: Cambridge University Press, 1986); Patricia Crone, God's Rule: Government and Islam (New York: Columbia University Press, 2004).

27. Brinkley Messick, The Calligraphic State: Textual Domination and History in a Muslim Society (Berkeley: University of California Press, 1993).

28. Sherman Jackson, Islamic Law and the State: The Constitutional Jurisprudence of Shihāb al-Dìn al-Qarāfī (Leiden: E.J. Brill, 1996).

29. Wael B. Hallaq, "Was the Gate of Ijtihad Closed?" International Journal of Middle East Studies 16 (1984): 3-41; "On the Origins of the Controversy about the Existence of Mujtahids and the Gate of Ijtihad," Studia Islamica 63 (1986): 129-41.

30. Wael B. Hallaq, Sharī $`$ : Theory, Practice, Transformations (Cambridge: Cambridge University Press, 2009), 355-543.

31. Wael B. Hallaq, "Can the Shari'a be Restored?" in Islamic Law and the Challenges of Modernity, ed. Yvonne Y. Haddad and Barbara Stowasser (Walnut Creek, CA: Altamira Press, 2004), 21-53.

32. Wael B. Hallaq, The Impossible State: Islam, Politics, and Modernity's Moral Predicament (New York: Columbia University Press, 2013); Restating Orientalism: A Critique of Modern Knowledge (New York: Columbia University Press, 2018), chapter 5.

33. Talal Asad, The Idea of an Anthropology of Islam (Washington, DC: Center for Contemporary Arab Studies, Georgetown University, 1986), 14-17.

34. Talal Asad, Formations of the Secular: Christianity, Islam, Modernity (Stanford, CA: Stanford University Press, 2003), 159-201. 
35. Asad, Formations, 205-56; Talal Asad, "Law, Ethics, and Tradition in the Story of Egyptian Modernization," in Religion and Its Other: Secular and Sacral Concepts and Practices in Interaction, eds. Heike Bock, Jörg Feuchter, Michi Knecht (Berlin: Campus Verlag, 2008).

36. In contrast to Hallaq's exploration of ijtihad and the one who practices it (the mujtahid), Mohammad Fadel explores the subjectivity of the muqallid (one who follows earlier precedent); Mohammad Fadel, "Istafti qalbaka wa in aftāka al-nasu wa aftāka': The Ethical Obligations of the Muqallid between Autonomy and Trust" in Islamic Law in Theory: Studies on Jurisprudence in Honor of Bernard Weiss, ed. A. Kevin Reinhart and Robert Gleave (Leiden: Brill, 2014), 105-26.

37. Șaḥih Muslim 1716a: "When a judge gives a decision, if he exercises ijtihād and is right, there are two rewards for him; and if exercises ijtihād but is wrong, there is one reward for him." Translation modified from Sunnah. com.

38. Max Weber, Economy and Society: An Outline of Interpretive Sociology, trans. Ephraim Fischoff et al. (Berkeley: University of California Press, 1978), 2:976-78.

39. Joseph Schacht, The Origins of Muhammadan Jurisprudence (Oxford: Oxford University Press, 1953).

40. Consider how Knut Vikør starts his introduction to Islamic legal thought by discussing the assumptions of what law represents in modern Anglo-American situations. See his Between God and the Sultan: A History of Islamic Law (London: Hurst \& Co, 2005).

41. On liberal subjectivity and ritual performance, see Saba Mahmood, Politics of Piety: The Islamic Revival and the Feminist Subject (Princeton: Princeton University Press, 2005), 118-53.

42. Ibn Rushd, The Distinguished Jurist's Primer, trans. Imran Ahsan Khan Nyazee (Reading, UK: Garnet, 1994).

43. Dominique Urvoy, Ibn Rushd, Averroes (London: Routledge, 1991).

44. Ibn Rushd, The Distinguished Jurist's Primer, 1-93.

45. Ibid., 96-259.

46. Ibid., 259-83.

47. Ibid., 283-328.

48. Ibid., 330-61.

49. Hussein Ali Agrama, "Ethics, Tradition, Authority: Toward An Anthropology of the Fatwa," American Ethnologist 37, no. 1 (2010): 2-18; Questioning Secularism: Islam, Sovereignty, and the Rule of Law in Modern Egypt (Chicago: University of Chicago Press, 2012), 160-87.

50. Consider Michel Foucault, Technologies of the Self: A Seminar with Michel Foucault, ed. Luther H. Martin, Huck Gutman, and Patrick H. Hutton (Amherst: University of Massachusetts Press, 1988), 16-49. 
51. Christian Lelong, dir., Justice à Agadez (Annecy, France: Cinédoc Films, 2004).

52. Against Weberian stereotypes of Islamic judges, consider also David S. Powers, "Kadijustiz or Qāḍi-Justice? A Paternity Dispute from Fourteenth-Century Morocco," Islam Law and Society 1 no. 3 (1994): 332-66.

53. Consider al-Juwaynī’s well-known thought experiment about the Shāfi'i mujtahid married to the Hanafī mujtahid. They do not need to read al-Juwaynī as saying this was a common situation, but that following a different legal rite to one's spouse can illustrate significant features about Islamic legal authority.

54. Saba Mahmood, Religious Difference in a Secular Age: A Minority Report (Princeton: Princeton University Press, 2016), 31-65.

55. Saba Mahmood, "Religious Freedom, the Minority Question, and Geopolitics in the Middle East," Comparative Studies in Society and History 54 (2012): 418-46.

56. Mahmood, Religious Difference, 111-48.

57. Ovamir Anjum, Politics, Law and Community in Islamic Thought: The Taymiyyan Moment (Cambridge: Cambridge University Press, 2012); Jon Hoover, Ibn Taymiyya (London, Oneworld, 2019).

58. Muhammad Umar Memon, Ibn Taimìya's Struggle Against Popular Religion: With An Annotated Translation Of His Kitāb "Iqtiḍā' aș-sirāt al-mustaqìm mukhālafat aṣhāb al-jahı̀im” (The Hague: Mouton, 1976).

59. Mahmood is critical of Pierre Bourdieu's use of the term habitus without engaging the older classical tradition. See Mahmood, Politics of Piety, 134-39.

60. Against the uncritical valorization of diversity, see David Nirenberg, Neighboring Faiths: Christianity, Islam, and Judaism in the Middle Ages and Today (Chicago: University of Chicago Press, 2014). 